\title{
Estimation of Soil Losses in a Slope Area of Tokat Province through USLE and WEPP Model
}

\author{
Saniye Demir ${ }^{1 *}, \operatorname{İrfan}_{\text {Oğuz}}{ }^{1}$, Erhan Özer ${ }^{2}$

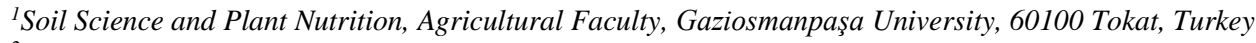 \\ ${ }^{2}$ Middle Black Sea Passage Agricultural Research Institute F. 60250 Tokat, Turkey
}

\section{A R T I C L E IN F O}

\section{Research Articles}

Received 18 October 2018 Accepted 10 December 2018

\section{Keywords:}

Universal soil loss equation

WEPP model

Soil loss

Soil properties

Land use

\section{A B S T R A C T}

Tokat is one of the developing provinces in terms of urbanism. Therefore, the land use changes city-wide which closely affects soil erosion. Numerical estimation of soil erosion is very important to prevent soil losses. In this study, USLE and WEPP Hillslope model were used to estimate the long-term soil losses in a slope area which used to be a pasture land and then turned into a fruit orchard in Büyükbeybağ sensitivity of the soil in the slope area was detected to be very low. Erosivity value of the area is low, soil is resistant to erosion due to pasture land use type and fruit orchard use type does not require intense soil cultivation practices. For all these reasons, both estimation technologies estimated soil losses of the land to be low.

\section{Tokat İlin'de Bir Yamaç Arazide Toprak Kayıplarının USLE ve WEPP Model ile Tahmin Edilmesi}

M A K A L E B İ L G İ S İ

\section{Araștırma Makalesi}

Geliş 18 Ekim 2018

Kabul 10 Aralık 2018

Anahtar Kelimeler:

Üniversal toprak kaybı eşitliği

WEPP model

Toprak kayb1

Toprak özellikleri

Arazi kullanımı

\section{Ö Z}

Tokat, şehircilik bakımından gelişmekte olan illerden birisidir. Bundan dolayı il genelinde arazi kullanımı değişmekte ve bu durum toprak erozyonunu çok yakından etkilemektedir. Toprak erozyon miktarının sayısal olarak tahmin edilmesi, toprak kayıplarının engellenmesinde çok önemlidir. Bu çalışmada, Tokat ili Büyükbeybağı mevkiinde yer alan önceden mera arazi kullanım türünde olup, daha sonra meyve bahçesine dönüştürülmüş bir yamaç arazide meydana gelen, uzun yıllık toprak kayıpları USLE ve WEPP Hillslope modeli ile tahmin edilmiştir. Yamaç arazisinde yer alan toprakların aşınıma duyarlılığı oldukça düşük olarak belirlenmiştir. Yörenin erosivite değerinin düşük, mera kullanım türünden dolayı toprakların erozyona dayanıklı olması ve meyve bahçesi kullanım türünün yoğun toprak işleme uygulamalarını gerektirmemesine bağlı olarak, her iki tahmin teknolojisi de arazinin toprak kayıplarını düşük olarak tahmin etmiştir.

\footnotetext{
"Sorumlu Yazar:

E-mail: saniye.demir@gop.edu.tr
} 


\section{Introduction}

Today, soil erosion is defined as a serious environmental problem as a combination of intense agricultural activities, soil degradation and precipitation intensity. This phenomenon is a natural process which causes the transport of fertile topsoil and contamination of surface water (Pieri et al., 2007). Especially due to snow melting commonly seen in spring and also soil processing with plough, a considerable number of soil losses occurs (Dehvari, 2014). Studies indicate that soil losses will increase in many parts of the world due to the change in the hydraulic cycle as a result of the climate change. Many plans and management methods have been developed to reduce soil losses in hillslopes and basins. Storage capacities of existing dams are very valuable and non-renewable resources must be protected against sediment damages (Karaş and Oğuz, 2005).

The concept of soil loss by erosion has may more destructive effects, especially on arid and semi-arid ecosystems (Cornelis, 2006; Rebeca et. al. 2011). It is reported that besides the warming above the normal conditions, the precipitation incapacity and evaporation events, which cause the current water to become scarce enough to put the life of the creatures at risk, are also important influences on the conceptual definition of drought (Kezik and Kocaçınar, 2014; Hacısalihoğlu, 2018). Where annual rainfall less than $300 \mathrm{~mm}$ is arid, annual precipitation is places between $300-600 \mathrm{~mm}$ is defined as semi-arid regions (FAO, 1963; Ürgenç, 1998). A large part of Turkey is classified as arid and semi-arid (Figure 1). Southeastern and Central Anatolia regions are classified as semi-arid regions.

Erosion causes land degradation by removing the soil from where it originates and by depositing the sediment on other productive land (Karaş and Oğuz, 2017). In recent years, many erosion models have been introduced in which decomposition, transportation and accumulation processes of the eroded soil are numerically explained (Bajracharya and Lal, 1998; Toy et al., 2002). Initial studies investigated the factors affecting soil erosion, such as precipitation, soil properties, surface flow, topography and vegetation (Wischmeier and Smith, 1978; Renard and Freimund, 1994). Since erosion processes are highly complex and associated with many parameters, the calibration of the models is very difficult. Specifically, data defining the general characteristics of the land are inadequate and their content varies depending on the area and time. Mathematical models are widely in use today because their algorithms are simple and easy to use. These models calculate and calibrate soil losses based on the observed data. Therefore, they cannot simulate erosion processes that emerge as a result of physical processes. Currently, USLE is the most widely used mathematical erosion model (Laflen et al., 1991). It predicts the soil losses occurring in an area according to a numerical equation.

Process-based models are able to predict both sediment transport and accumulation processes. This property boosts the performance of the model (Walling et al., 2003). The results obtained from these models are of utmost importance in carrying out the conservation plans of lands and in evaluating the water quality (Zhang,
2017). However, the inadequacy of areal data pertaining to soil erosion factors has a negative impact on the development and evaluation of these models (Walling et al., 2003; Parsons et al., 2004). Due to the inadequacy of these data, it is not possible to compare the observed and simulated data, therefore the model can be evaluated to a limited extent (Tiwari et al., 2000; Amore et al., 2004).

Sparovek et al. (2000) predicted soil losses occurring in a sugar beet cultivated land in the southeast of Brazil via USLE, WEPP and ${ }^{137} \mathrm{Cs}$ models. The highest soil loss was found by the USLE and the lowest by the WEPP model. Researchers stated at the end of the study that while determining a method for predicting soil losses, the method should be in accordance with all the characteristics of the selected area.

Amore et al. (2004) predicted the soil losses occurred in three different basins in Italy using the USLE and WEPP models and compared the results found. At the end of the study, while the WEPP model predicted the soil losses close to the observed values, USLE made a higher estimation.

Christie et al. (2013) simulated soil losses occurred on the hillslopes with different sloping values located in the ridge, valley and blue hill in the state of Virginia with USLE and WEPP models. They collected 5 soil samples from each region. While the USLE estimated soil losses 4 or 45 times higher in the steep hillslopes compared to hillslopes with lower slope values, the WEPP model estimated a 4 times higher value.

In this study, it is aimed to predict soil losses occurring in the sloping land located in the Büyükbeybağ district of Tokat province. The sloping land was used as a pasture land for many years, then it has been transformed into an orchard. In the study, it was aimed to predict soil losses by means of USLE, a mathematical method, and WEPP, a process-based method, and evaluate the performance of both models under climate conditionals of Tokat province by comparing the results obtained.

\section{Material and Method}

Büyükbeybağı neighbourhood is located in the centre of Tokat province and is situated between $44^{\circ} .62^{\prime}$ northern latitudes and $32^{\circ} .29^{\prime}$ eastern longitudes. The total land area is 1000 ha and the slope value is $20 \%$. The study area was used as pasture until 2013; it has since been converted into an orchard and at the same time was terraced. Apple, cherry and quince fruit types are found in the mixed garden.

Since Tokat province is located in the inner part of the Central Black Sea region, it is under the influence of both the Black sea and continental climate of Central Anatolia. Summers are hot and dry, winters are cold and rainy. Due to the increase in elevation, the winter season is experienced quite harshly from the north to the south. Precipitation is the highest in the spring season, but summers are quite dry. According to the precipitation data obtained from Tokat Meteorology Station between 19672017, the maximum and minimum annual precipitation is $\mathrm{mm}$ and $\mathrm{mm}$, respectively. Approximately 66 days of a year is rainy. The highest precipitation is seen in spring 
and autumn months. According to the data between 19672016, the lowest temperature is seen in January with -10.7 ${ }^{\circ} \mathrm{C}$ and the highest temperature is $36.5{ }^{\circ} \mathrm{C}$ in July. The average annual temperature is $12.5{ }^{\circ} \mathrm{C}$ (Anonymous, 2015).

\section{Universal Soil Loss Equality (USLE)}

Universal soil loss equality (USLE) is an erosion model that is widely used today, predicting long-term annual average soil losses occurring in a sloping land. The model mathematically calculates the soil losses by taking into account the precipitation parameters of the region, soil type, topography, product system and management practices. USLE calculates soil losses that develop due to layer or rill erosion in a single sloping land. Gully cannot additionally calculate the erosion that occurs due to wind or soil tillage. The model can calculate soil losses occurring in lands on which a special product and management practices are applied and determine the erosion occurring in the regions where there are no agricultural activities such as construction area. The soil loss values found by the model and the soil loss tolerance values of the region can be compared.

The characteristics of the models used in the study are presented in Table 1. The USLE (Universal Soil Loss Equation), (Wischmeier and Smith, 1978) was developed in 1978 based on statistical analysis results of precipitation and precipitation simulation data belonging to an area more than $10,000 \mathrm{~m}$. It uses a simple equation given below:

$$
\mathrm{A}=\mathrm{K} \times \mathrm{R} \times \mathrm{L} \times \mathrm{S} \times \mathrm{C} \times \mathrm{P}
$$

Here, A refers to the expression of land losses in tons occurring in 1 hectare of land annually. $\mathrm{R}$ is the precipitation erosion factor and is calculated according to the maximum precipitation of 30 minutes. The greater the duration and the intensity of precipation in a region, the greater the probability of an erosion. $\mathrm{K}$ denotes the resistance displayed by the soil particles against decomposition and transportation. The $\mathrm{K}$ factor, which is closely affected by the texture of the soil, is also affected by the structure, organic matter content and the conductivity of the soil. L defines the hillslope length and $\mathrm{S}$ defines the land with a slope degree. It is likely that more soil losses occur especially on steep and long lands. $\mathrm{C}$ is the vegetation factor and does not have a unit. It is used in measuring the soil losses occurring in agricultural lands or non-agricultural lands having diversified vegetation. Soil losses that occur as a result of agricultural activities below or at the top of the hillslope is $\mathrm{P}$, which is the soil conservation factor. This value reflects the effect of practices that reduce and control the surface flow that develops due to precipitation.

Table 1 Main characteristics of the erosion models used in the study

\begin{tabular}{c|llcccc}
\hline \multirow{2}{*}{ Model } & \multicolumn{1}{c}{$\begin{array}{c}\text { Model } \\
\text { Type }\end{array}$} & $\begin{array}{c}\text { Application } \\
\text { Area }\end{array}$ & $\begin{array}{c}\text { Hydraulic } \\
\text { Processes }\end{array}$ & $\begin{array}{c}\text { Erosion } \\
\text { Processes }\end{array}$ & $\begin{array}{c}\text { Data } \\
\text { Inputs }\end{array}$ & $\begin{array}{c}\text { Application in } \\
\text { Tokat Province }\end{array}$ \\
\hline \multirow{2}{*}{ USLE } & Numerical & Hillslope & High Infiltration & $\begin{array}{l}\text { Layer and } \\
\text { Rill erosion }\end{array}$ & Low & $\begin{array}{c}\text { Since 1997 to } \\
\text { today }\end{array}$ \\
WEPP & $\begin{array}{l}\text { Based on a } \\
\text { physical } \\
\text { process }\end{array}$ & $\begin{array}{l}\text { On a basin } \\
\text { smaller than a } \\
\text { hillslope }\end{array}$ & High Infiltration & $\begin{array}{l}\text { Layer and } \\
\text { Rill erosion }\end{array}$ & Very high & 2016 \\
\hline
\end{tabular}

The $\mathrm{R}$ factor belonging to the study area was calculated using the $\sum \mathrm{EI}_{30}$ formula (Chung et al., 1983; Park et al., 2000). E is expressed as the total kinetic energies of precipitation and $\mathrm{I}_{30}$ as the intensity of maximum 30 minute-precipitation. The $\mathrm{K}$ factor was calculated according to the equation developed by Wischmeier and Smith (1978). The inclination and the length of the hillslope (1: 25.000) were determined according to the soil map. The $\mathrm{C}$ factor that stands for the vegetation was calculated according to the land use. Soil conservation factor $\mathrm{P}$ was taken as 1 because the study area does not require soil protection measures.

\section{Water Erosion Prediction Project Model (WEPP)}

WEPP (Water Erosion Prediction Project Model) (Flanagan and Nearing, 1995) is an erosion model that can predict soil losses and surface flow occurring due to the individual precipitation events at intervals with changing long-year averages (Laflen et al., 2004). It is based on the physical process and simulates the erosion developing in association with water according to daily precipitation data. It calculates the surface flow and soil losses and accumulations that develop due to individual precipitation. The model presents the events occurring during the simulation process daily, monthly and yearly in the model output. It also elaborately shows the events that take place in different lengths and sloping value of the hillslopes (Flanagan and Nearing, 1995).

Hillslope variant of the WEPP model (version 4.3) was used in the study. The model uses 4 data input files which include climate, slope, management and soil file. 50-year precipitation parameters of 1967-2016 were used. These parameters are climate, temperature, solar radiation, relative humidity and wind data. These data are simulated by CLIGEN climate model and constitute the model's climate file. Different slope, management and soil files were created for pasture and orchard. The WEPP soil input files include measured soil parameters such as hydraulic conductivity, cation exchange capacity, organic matter content (Flanagan and Livingston, 1995). The interrill and rill erodibility parameters were determined using percentage of very fine sand and percentage of organic matter. The critical shear stress was determined using percentage of clay and percentage of fine sand (Flanagan and Livingston, 1995). Vegetation reduces the erosion rate by intercepting raindrops, reduces runoff, and improves infiltration (Lal, 1994). Land use/cover data is crucial in soil erosion models (Renard et al., 1997; Yuksel et al., 2007; Landi et al., 2011). 


\section{Findings and Discussion}

\section{Precipitation Characteristics}

1967-2016 precipitation data of the study area were simulated with CLIGEN climate model. Figure 1 shows the annual precipitation series, which were observed in the study area and simulated by CLIGEN. The long-years average of the observed precipitation was $431.7 \mathrm{~mm}$. As can be seen from Figure 1, the precipitation above the average of long-years is sparse, but occurs in a higher number, whereas precipitation below the average of longyears is more intense, but occurs in a smaller number. It is seen that Tokat province was affected by drought considerably between 1969-1976 and 1998-2007 especially.

A multi-year average of precipitation simulated by CLIGEN is $384.96 \mathrm{~mm}$. In the 50-year period, the model predicted 27 years above the average and 23 years below the average (Figure 1). Although the general characteristics of the precipitation were similar to the observed precipitation, it predicted the extreme precipitation events below the average of the observed precipitation and predicted the precipitation events smaller than $2 \mathrm{~mm}$ above the average.

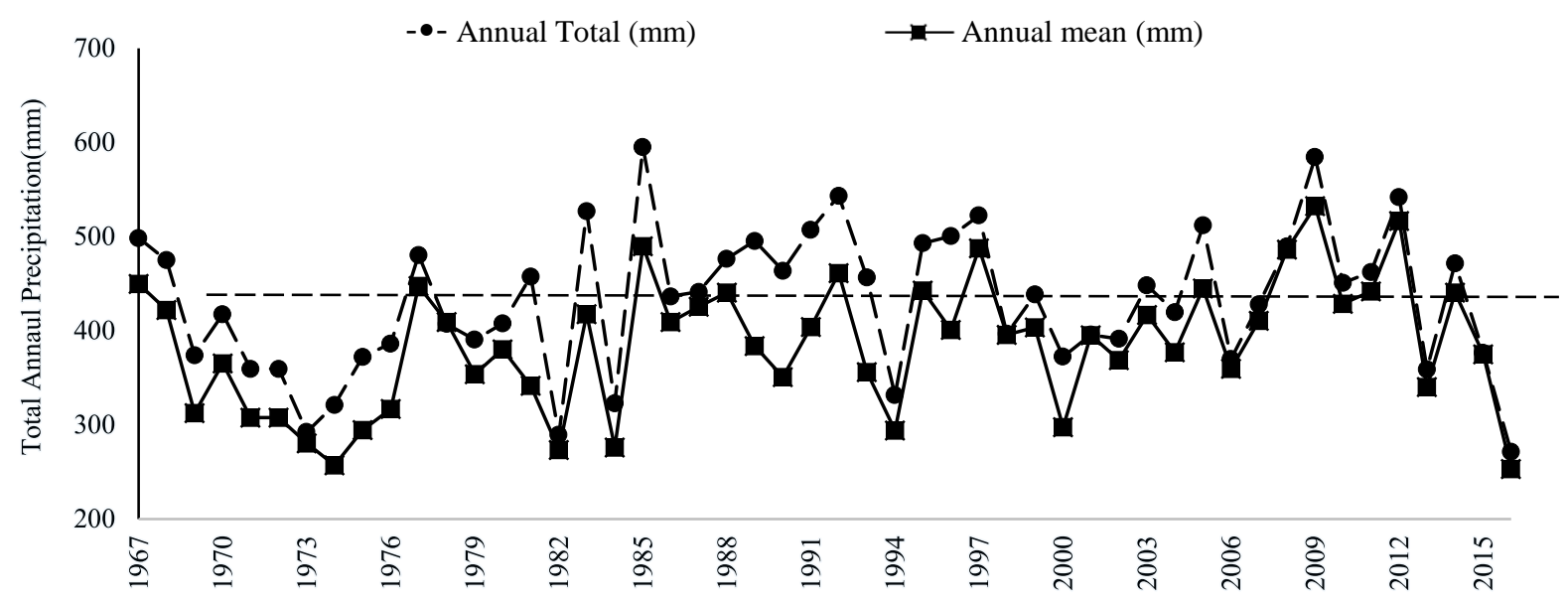

Figure 1 Precipitation series of Observed and CLIGEN precipitation data

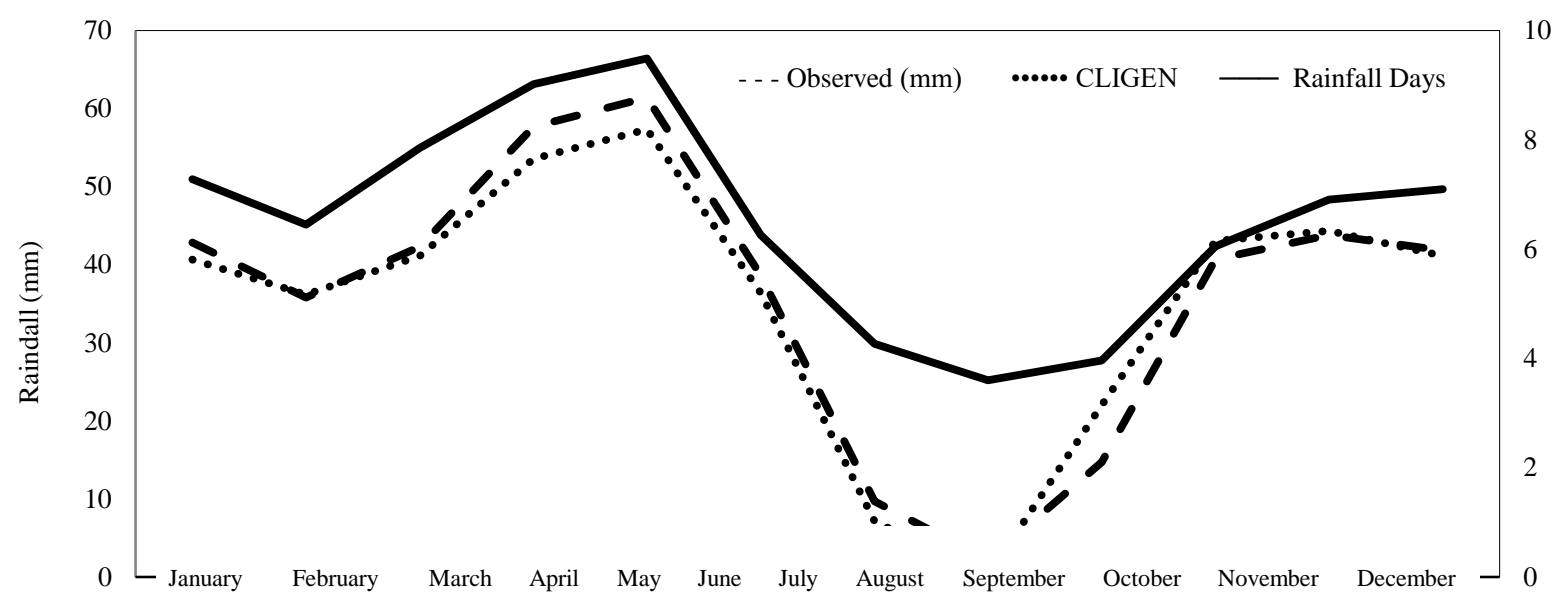

Figure 2 Average precipitation and number of wet days per month between 1967-2016

In regions with arid and semi-arid climates, precipitation characteristics vary widely. The average precipitation, which was observed monthly for years between 1967 and 2016 and simulated with CLIGEN, is depicted graphically in Figure 2. It is seen that both the observed and simulated precipitation are distributed uniformly. In the case of both precipitations, the winter and summer months are arid; spring and autumn months are quite rainy (Figure 2). While CLIGEN predicted the spring months below the observed value; it predicted the precipitation seen in the autumn months quite close, despite being slightly above the average. Due to snow melting in spring, the soil water content is very high. The model does not include the observed precipitation in the budget and predicts at a lower rate. Yet again in these months, consecutive extreme precipitation is seen a lot. The number of wet days and accordingly total precipitation increase (Figure 2). Precipitation seen in the autumn after a dry summer increases the water content of the soil. Due to the algorithm of the model, the water budget shows a rapid increase. Hence, it has a tendency to predict the precipitation higher. The high number of wet days and precipitation in the spring months can be considered as an indication that soil losses will be higher in these months. 
Comparison of USLE and WEPP Model Estimated Soil Losses

The soils in the study area were found to be highly resistant to erosion since they used to be pasture lands. The characteristics of the study area soils are given in Table 1. During the transformation of the land into a sandy, argillaceous and loamy textured orchard, a decrease was observed in the organic matter content due to soil tillage.

The average annual soil losses were calculated by using USLE and WEPP models in the pastures and orchards in Büyükbeybağı district and the results are presented in Table 3. While the average annual soil loss estimated with USLE in the pasture area was $1.84 \mathrm{t}^{\mathrm{ha}} \mathrm{ha}^{-1} \mathrm{yr}^{-}$ ${ }^{1}$, no soil loss was estimated with the WEPP model (Table $3)$. In the orchard, the average soil loss of $5.40 \mathrm{t} / \mathrm{ha}^{-1} \mathrm{yr}^{-1}$ was estimated with USLE and $0.484 \mathrm{t}^{\mathrm{ha}} \mathrm{ha}^{-1} \mathrm{yr}^{-1}$ with the WEPP (Table 3).

Table 2 Product and soil properties used in erosion models of Büyükbeybağı location

\begin{tabular}{l|cc}
\hline \multirow{2}{*}{ Soil Properties } & \multicolumn{2}{|c}{ Type of Land Use } \\
\cline { 2 - 3 } & Pasture & Orchard \\
\hline Sand \% & 51.33 & 51.33 \\
Clay \% & 23.33 & 23.33 \\
Organic Matter Amount \% & 5.91 & 3.99 \\
Very Thin Sand \% & 3.20 & 3.76 \\
\hline
\end{tabular}

Table 3 Comparison of soil losses estimated with erosion models

\begin{tabular}{l|cc}
\hline \multicolumn{1}{c|}{ Erosion Models } & \multicolumn{2}{|c}{ Land Use } \\
\cline { 2 - 3 } & Pasture & Orchard \\
\hline $\begin{array}{l}\text { Soil Losses Estimated } \\
\text { with USLE }\left(\mathrm{t} / \mathrm{ha}^{-1} \mathrm{yr}^{-1}\right)\end{array}$ & 1.84 & 5.40 \\
$\begin{array}{l}\text { Soil Losses Estimated } \\
\text { with WEPP }\left(\mathrm{t} / \mathrm{ha}^{-1} \mathrm{yr}^{-1}\right)\end{array}$ & 0.000 & 0.484 \\
\hline
\end{tabular}

In all of the different types of land use, the USLE model predicted land losses higher than the WEPP model. There are many underlying reasons for this. USLE does not carry the material that has been decomposed and transported into the study area outside the area and calculates all the losses within the study area. The $\mathrm{R}$ and LS factor are the same for both land uses, and land use and soil tillage factors have been very influential in the calculation of soil losses. The WEPP model uses very different properties of soil and hillslope together in estimating soil losses. In particular, tools and equipment along with methods used in soil tillage are very important; whereas, USLE does not consider these features.

Cecilio et al. (2004) used WEPP model to predict soil losses in their study in the pasture with sandy, clayey and loamy texture in Brazil, and the model did not predict any soil loss. These results support the results obtained in our study. Tiwari et al. (2000) compared WEPP and USLE erosion models in 20 USLE areas. They found that the WEPP model yielded more successful results in approximately $85 \%$ of these areas.

During the transformation of the pasture land into an orchard, tillage and terracing were done. Since fruit trees are planted in the spring, the soil is processed in the rainy period. This situation causes the pores to disintegrate and results in soil compaction (Rasiah et al., 2004). With reduced porosity on the soil surface, hydraulic conductivity declines. These conditions affect the input parameters of the WEPP model very deeply. Extreme precipitation, in particular, increases the number of wet days for the model and accelerates soil loss formation.

\section{Conclusion}

Accurate estimation of soil erosions that occur in association with water is very important in terms of serious environmental problems such as the decline in soil fertility and water quality and soil losses on cultivated lands. However, it is very difficult, time consuming and expensive to estimate erosion in sloping lands in Tokat province due to the different land use and diversified vegetation in the region. Therefore, widespread use of erosion models such as USLE and WEPP in Tokat province would be very useful. The WEPP hillslope model works with a database that contains a lot of inputs yet these databases are not available in our country. For this reason, it is necessary to carry out studies that will promote the use of the WEPP model.

Lower soil losses were predicted with the WEPP model in the sloping land which used to be a pasture and later was transformed into orchard in Büyükbeybağ 1 district. However, comparisons on erosion should be based on objective criteria that can be similarly measured and assessed. Therefore, it is necessary to conduct further studies based on data observed in the region in order to estimate the soil losses numerically and to offer suggestions related to soil conservation.

\section{References}

Anonim. 2015. Tokat Meteoroloji İstasyonu.

Amore E, Modica C, Nearing, MA, Santoro VC. 2004. Scale Effect İn USLE And WEPP Application for Soil Erosion Computation from Three Sicilian Basins. J. Hydrol. (293): 100-114.

Bajracharya RM, Lal R. 1998. Crusting Effects on Erosion Processes Under Simulated Rainfall on A Tropical Alfisol. Hydrol. Process. (12): 1927-1938.

Cecilio RA, Rodriguez RG, Baena LGN, Oliveira FG, Pruski FF, Stephan AM, Silva JMA. 2004. Analysis of The RUSLE and WEPP Models for A Small Watershed Located İn Vicosa, Minas Gerais State, Brazil, in: ISCO-International Soil Conservation Organızation Conference.

Christie AM, Aust WM, Zedaker SM, Strahm BD. 2013. Potential Erosion from Bladed Firelines in The Appalachian Region Estimated with USLE-Forest and WEPP Models. South. J. Appl. For. (37): 140-147.

Chung PK, Koh MH, Im JN, Eum KT, Choi DW. 1983. Rainfall Erosion Factor for Estimating Soil Loss. J. Korean Soc. Soil Sci. Fertil. (Korea Republic).

Cornelis WM. 2006. Hydroclimatology of wind erosion in arid and semiarid environments. Chapter 9. Dryland Ecohydrology, D'Odorico and A. Porporato (eds.), 141-159. Springer. Printed in the Netherlands. Print ISBN: 978-14020-4259-1.

Dehvari A. 2014. Estimation of Surface Runoff and Sediment Yield Using WEPP Model in Southern Ontario, Canada. Int. J. Agric. Crop Sci. (7): 876.

FAO. 1963. Tree Planting Practices for Arid Zones, Food and Agriculture Organization of The United Nations, Rome. Available from: www.fao.org/docrep/012/al040e/al040e00. pdf (Accessed 5 April 2018). 
Flanagan DC, Nearing MA. 1995. USDA-Water Erosion Prediction Project: Hillslope Profile and Watershed Model Documentation. NSERL Report.

Hacisalihoglu S. 2018. Semi-Arid Plantation by Anatolian Black Pine and Its Effects on Soil Erosion and Soil Properties. Turkish Journal of Agriculture - Food Science and Technology. 6(4): 500-507.

Karaş E, Oğuz İ. 2005. Sakarya Porsuk Sarısu Havzasında CORINE, LEAM ve USLE Metodolojilerinin Kullanılarak Erozyon Risk Haritalarının Hazırlanması.

Karaş E, Oğuz İ. 2017. Evaluation of Soil Erosion and Sustainable Land Use Management in the Sarısu Basin. Turkish Journal of Agriculture - Food Science and Technology. 5(8): 864-872.

Kezik U. Kocaçınar F. 2014. Kurak ve Yarı-Kurak Bölgelerde Yayılış Gösteren Quercus branthii L. Baltalıklarında Seyreltmenin Su Potansiyeli ve Sürgün Durumu Üzerine Etkisi. II. Ulusal Akdeniz Orman ve Çevre Sempozyumu. Akdeniz ormanlarının geleceği: Sürdürülebilir toplum ve çevre Isparta-Turkey, 22-24 September, Suleyman Demirel University, pp:117-127.

Laflen JM, Flanagan DC, Engel BA, 2004. Soil Erosion and Sediment Yield Prediction Accuracy Using WEPP. JAWRA J. Am. Water Resour. Assoc. (40): 289-297.

Laflen JM, Lane LJ, Foster GR, 1991. WEPP: A New Generation of Erosion Prediction Technology. J. Soil Water Conserv. (46): 34-38.

Lal R. 1994. Soil Erosion Research Method. Second Edition, Soil and Water Conservation Society:Ankeny, IA, USA, 352 p.

Landi1 A, Barzegar AR, Sayadi1 J, Khademalrasoul A. 2011. Assessment of Soil Loss Using WEPP Model and Geographical Information System. Journal of Spatial Hydrology. Vol.11, No.1

Park JH, Pyeon JG, Kim GI. 2000. A Study of Distribution of Rainfall Erosivity in USLE/RUSLE for Estimation of Soil Loss. J. Korea Water Resour. Assoc. (33): 603-610.

Parsons AJ, Wainwright J, Mark Powell D, Kaduk J, Brazier RE. 2004. A Conceptual Model for Determining Soil Erosion by Water. Earth Surf. Process. Landforms (29):1293-1302.

Pieri L, Bittelli M, Wu JQ, Dun S, Flanagan DC, Pisa PR, Ventura F, Salvatorelli F. 2007. Using the Water Erosion Prediction Project (WEPP) Model to Simulate FieldObserved Runoff and Erosion in the Apennines Mountain Range, Italy. J. Hydrol. (336): 84-97.

Rasiah V, Florentine SK, Williams BL, Westbrooke ME, 2004. The Impact of Deforestation and Pasture Abandonment on Soil Properties in The Wet Tropics of Australia. Geoderma (120): 35-45.
Rebeca VM, Eusebio VR, Klavdia O, Luis HS, Miguel ADC. 2011. Soil Erosion Processes in Semiarid Areas: The Importance of Native Vegetation, Soil Erosion, Danilo Godone and Silvia Stanchi, IntechOpen, DOI: 10.5772/23211. Available from: https://www.intechopen.com/ books/soil-erosion-studies/soil-erosion-processes-in-semiaridareas-the-importance-of-native-vegetation

Renard KG, Freimund JR. 1994. Using Monthly Precipitation Data to Estimate The R-Factor in the Revised USLE. J. Hydrol. (157): 287-306.

Renard KG, Foster GR, Weesies GA, McCool DK, Yoder DC. 1997. Predicting Soil Erosion by Water: A Guide to Conservation Planning with the Revised Universal Soil Loss Equation (RUSLE). U.S Department of Agriculture, Agricultural Handbook No. 703, Government Printing Office, Washington. DC, USA, $384 \mathrm{p}$.

Sparovek G, Bacchi OOS, Schnug E, Ranieri SBL, De Maria IE. 2000. Comparison of Three Water Erosion Prediction Methods (137Cs, WEPP, USLE) in South-East Brazilian Sugarcane Production. J. Agric. Trop. Subtrop (101): 107118.

Tiwari AK, Risse LM, Nearing MA. 2000. Evaluation of WEPP and İts Comparison with USLE and RUSLE. Trans. ASAE (43): 1129.

Toy TJ, Foster GR, Renard KG. 2002. Soil Erosion: Processes, Prediction, Measurement, and Control. John Wiley \& Sons.

Ürgenç S. 1998. Ağaçlandırma Tekniği, Yenilenmiş ve Genişletilmiş İkinci Baskı İ.Ü.Orman Fak.Yayınları, İ.Ü. Rektörlüğü Yayın No:3994, Orman Fakültesi, İstanbul Yayın no: 441, ISBN. 975-404- 446-5.

Walling DE, He Q, Whelan PA, 2003. Using 137Cs Measurements to Validate The Application of The AGNPS and ANSWERS Erosion and Sediment Yield Models in Two Small Devon Catchments. Soil Tillage Res. (69): 27-43.

Wischmeier WH, Smith DD. 1978. Predicting Rainfall Erosion Losses-A Guide to Conservation Planning. Predict. Rainfall Eros. Losses-a Guid. to Conserv. planning.

Yuksel A, Akay AE, Reis M, Gundogan R. 2007. Using the WEPP model to predict sediment yield in a sample watershed in Kahramanmaras region. International Congress River Basin Management, 2, 11-22.

Zhang XCJ. 2017. Evaluating Water Erosion Prediction Project Model Using Cesium-137-Derived Spatial Soil Redistribution Data. Soil Sci. Soc. Am. J. (81): 179-188. 